\title{
IMPLEMENTASI SENSOR PIEZOELECTRIC SEBAGAI MIDI DRUM CONTROLLER BERBASIS ARDUINO UNO
}

\author{
Andry Halomoan Ompusunggu, Joseph Dedy Irawan, Suryo Adi Wibowo \\ Program Studi Teknik Informatika S1, Fakultas Teknologi Industri \\ Institut Teknologi Nasional Malang, Jalan Raya Karanglo km 2 Malang, Indonesia \\ ompusungguandry@gmail.com
}

\begin{abstract}
ABSTRAK
Penelitian ini bertujuan untuk .membuat alat MIDI Drum Controller menggunakan Sensor Piezoelectric dan menguji kelayakan untuk bermain Drum itu sendiri. Alat yang dikembangkan ini sebagai alternatif bagi pemula yang ingin bermain Drum dan penggunaan membuat musik terutama pada aspek digital.

Piezoelectric adalah sebuah sensor yang dapat mendeteksi adanya getaran sehingga dapat membuat Dinamika pada saat memainkan Drum. Arduino digunakan sebagai penghubung antara sensor dengan aplikasi Drum yang mengerjakan bagaimana memproses sebuah bunyi ketika salah satu sensor ditekan.

Hasil dari penelitian ini berupa alat Drum Pad untuk pemain Drum ataupun orang yang ingin belajar Drum berbasis Arduino menggunakan Midi sebagai format output yang digunakan. Alat ini dapat bekerja dengan baik, dilihat dari real time antara alat yang dimainkan dengan bunyi yang dihasilkan, serta Velocity sebagai keraspelannya sebuah pukulan drum.
\end{abstract}

Kata Kunci : MIDI, Piezoelectric, Drum Pad

\section{PENDAHULUAN}

Musik adalah suara yang disusun sedemikian rupa sehingga mengandung nada, irama, lagu, dan keharmonisan terutama dari alat dan suara dari makhluk hidup yang berbunyi. Mendengarkan musik adalah sejenis hiburan, sehingga sangat memungkinkan diera sekarang untuk dijadikan sebuah pekerjaan tetap tentang seni. Membuat musik adalah salah satu cara untuk dijadikan sebuah karya. Dengan adanya era digital sangat memungkinkan untuk membuat musik dari sebuah komputer. Salah satu yang bisa dibuat adalah dengan menggunakan aplikasi pendukung Digital Audio Workstation (DAW), contohnya seperti FL Studio, Cubebase, dan Logic Pro. Untuk memudahkan dalam menggambar musik didalam aplikasi pendukung DAW.

Dengan perkembangan teknologi saat ini, musik sangat mudah dibuat dengan minimum alat dan komputer sederhana menggunakan aplikasi pendukung DAW. Menggambar melalui komputer adalah salah satu cara mengisi instrumen seperti gitar, drum, keyboard, dan lain-lain. MIDI Controller adalah salah satu solusi untuk memudahkan menggambar nada-nada, irama, dalam sebuah lagu. Drum adalah salah satu instrumen dasar untuk pembuatan sebuah lagu. Sehingga drum dapat di digitalisasi menggukanan MIDI Controller untuk memudahkan dalam pembuatan musik drum.

Oleh karena itu penulis bermaksud membuat alat implementasi Piezoelectric sebagai MIDI Drum Controler berbasis Arduino untuk membantu pembuatan musik supaya memudahkan dalam bermain drum elektrik. Dengan adanya alat ini membantu meringankan biaya untuk perekaman menggunakan drum asli dan memudahkan saat membuat musik.

\section{TINJAUAN PUSTAKA}

\subsection{Penelitian Terdahulu}

Rosy Edy Tamala pada tahun 2016 melakukan penelitian pada papernya dengan judul Pengembangan MIDI Drum Controller berbasis Mikrocontroller ATMEGA 2560. Dalam papernya penulis memaparkan bahwa pada penelitian ini bertujuan untuk menguji kelayakan produk MIDI Drum Controller. Produk yang dikembangkan ini merupakan produk alternatif untuk bermain drum bagi pemula. Metode yang digunakan dalam penelitian ini adalah Research and Development (R\&D). Hasil dari penelitian menunjukkan bahwa produk yang dihasilkan MIDI Drum Controller. Produk yang dikembangkan telah masuk ke dalam kategori baik dan dapat memenuhi kebutuhan para pemula. Hal ini dapat dilihat dari persentase kelayakan mencapai $84,5 \%$ yang diperoleh dari skor hasil penelitian yaitu diperoleh dari skor hasil penelitian yaitu 1014 dibagi dengan skor ideal yaitu 1200 apabila setiap responden memilih skor tertinggi pada setiap butir pada angket [1]

Selanjutanya pada paper Implementasi Fuzzy Logic dalam perancangan Drum Elektrik berbasis MIDI Menggunakan Perangkat Android dan Arduino Uno. Pada penelitiannya penulis mengimplementasikan logika fuzzy pada input perangkat android berupa pad drum elektrik yang memiliki sensor getar piezoelektrik untuk mendeteksi intensitas kekuatan pukulan yang dilakukan pengguna. Hasil dari penelitian ini diperoleh bahwa implementasi fuzzy logic pada sistem ini dapat menentukan output suara drum yang sesuai beradasarkan intensitas kekuatan pukulan yang dilakukan pengguna pada pad drum elektrik [2] 
Wahyu Kurniawan dengan penelitiannya yang berjudul Analisis dan perancangan perangkat keras Midi Drum Kit Elektrik berbasis mikrokontroller Arduino. Penelitian ini membuat Drum Elektrik dengan alat yang menyerupai Drum. Jadi fokus penelitian ini terletak pada alat yang menyerupai Drum. Hasil dari penelitian ini merupakan solusi dari Fungsional Drum dan dapat dibuat dengan harga yang lebih terjangkau[3]

Pada penelian Faisal dengaan papernya yang berjudul Rancang bangun perangkat Drum Elektrik Berbasis Mikrokontroller dengan memanfaatkan Bahan Plastik. Penelitian ini difokuskan pada software drum MIDI Addactive Drum dan penggunaan daur ulang dalam pembuatan alat. Jenis penelitian yang digunakan adalah penelitian kualitatif dengan stategi penelitian design and creation, teknik pengumpulan data menggunakan observasi, studi literatur. Hasil penelitian menunjukkan keefktifan dalam penggunaan yang telah dibuat. Dari segi teknis, drum MIDI elektrik dari bahan limbah daur ulang telah memiliki bentuk yang sesuai seperti drum elektrik yang dijual dipasaran[4]

Angki Noperbriansyah Pratama pada penelitian pengembangan midi controller berbasis microcontroller dengan mekanisme sentuh. Metode yang digunakan dalam penelitian ini adalah Research and Development (R\&D), dengan subjek penelitian musisi yang berjumlah 30 orang yang terdiri dari 3 elemen, yaitu musisi band, musisi recording, dan mahasiswa seni musik UNY. Hasil penelitian membuktikan bahwa pengembangan MIDI controller berbasis microcontroller dengan mekanisme sentuh layak digunakan. [5]

\subsection{Dasar Teori}

\subsubsection{Drum Elektrik}

Drum adalah kelompok alat musik perkusi yang terdiri dari kulit yang direntangkan dan dipukul dengan tangan atau sebuah batang. Selain kulit, drum juga digunakan dari bahan lain, misalnya plastik. Dalam musik pop, rock, dan jazz, drum biasanya mengacu kepada drum kit atau drum set, yaitu sekelompok drum yang biasanya terdiri dari snare drum, tom-tom, bass drum, cymbal, dan hi-hat. Orang yang memainkan drum disebut ,drummer". Dalam bukunya Madhumita Dutta (2008), yang dimaksud drum elektrik adalah: "Electronic drum is a percussion instrument in which the sound is generated by an electronic wafeform generator or sampler, instead of by acoustic vibration. When an electronic drum pad is struck, a voltage change is triggered in the embedded force sensitiveresistor".

Drum elektrik atau drum digital adalah sebuah perangkat yang disusun meniru bentuk drum akustik pada umumnya. Permukaan drum elektrik dibuat dari bantalanbantalan karet yang masing-masing bantalan diberi sensor. Fungsi sensor pada masing-masing bantalan karet tersebut adalah memberikan sinyal listrik ketika permukaan bantalan karet mendapat tekanan atau pukulan. Lalu sinyal listrik yang dihasilkan sensor akan diubah menjadi sinyal digital oleh modul elektronik yang kemudian dikirimkan ke soundbank modul atau perangkat komputer yang sudah terinstal software drum virtual.

Drum digital pertama kali diciptakan oleh seorang pemain drum bernama Graeme Edge. Graeme Edge adalah salah satu personil dari band bergenre blues dari Inggris bernama The Moody Blues. Graeme Edge bekerja sama dengan Professor Brian Groves dalam membangun perangkat drum elektrik yang kita kenal sekarang ini.

\subsubsection{Sensor Piezoelektrik}

Sensor adalah detektor yang memiliki kemampuan untuk mengukur beberapa jenis kualitas fisik yang terjadi, seperti tekanan atau cahaya. Sensor kemudian akan dapat mengkonversi pengukuran menjadi sinyal yang dapat dibaca. Sebagian besar sensor yang digunakan saat ini benar-benar akan dapat berkomunikasi dengan perangkat elektronik yang akan melakukan pengukuran dan perekaman.

Sensitivitas sensor menentukan banyak aplikasi sensor itu sendiri. Ketika sensor merespon perubahan yang relatif besar dalam suatu medium dengan perubahan yang relatif kecil dengan detektor material dan output yang konsekuen, itu menunjukkan sensitivitas rendah. Tapi kadang-kadang diperlukan sensor untuk mengukur perubahan kecil, dalam hal ini sensor dituntut untuk menunjukkan sensitivitas tinggi, menanggapi secara signifikan untuk perubahan dalam medium dibawah pengukuran. Seringkali, linearitas sensor tersebut terbatas pada kisaran yang dibatasi, diluar itu akan merespon tidak akurat (Syam. 2013).

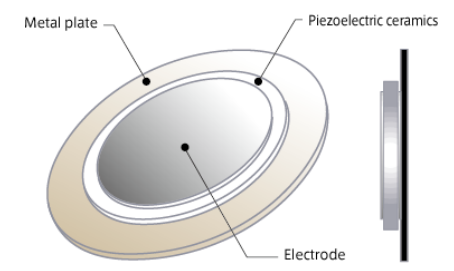

Gambar 1. Sensor Piezoelectric

Material piezoelektrik (pada umumnya berupa kristal batuan, keramik, termasuk tulang dan polimer) memiliki kemampuan untuk membangkitkan potensial listrik sebagai respon dari tegangan mekanik yang diberikan pada material tersebut. Material piezoelektrik ini bersifat reversibel, dimana terdapat efek piezoelektrik langsung (direct piezoelectric effect) yaitu produksi potensial listrik akibat adanya tekanan mekanik dan efek piezoelektrik balikan (converse piezoelectric effect) yaitu produksi tekanan akibat pemberian tegangan listrik yang menghasilkan perubahan dimensi, contohnya adalah kristal lead zirconate titanate yang akan mengalami perubahan dimensi sampai maksimal $0.1 \%$ jika diberi tegangan listrik. 
Sensor piezoelektrik secara umum dapat mendeteksi jenis-jenis tekanan dalam bentuk suara. Piezoelectric sensor diletakkan pada bagian instrumen yang dikenal sebagai kotak mikrofon. Secara teknik sensor piezoelectric dapat berperan sebagai sensor dan juga sebagai actuator. Manfaat piezoelectric lainnya adalah:

a. Piezoelectric elemen dapat mendeteksi dan pembangkit gelombang sonar.

b. Piezoelectric microbalance dapat sebagai sensor biologi dan kimia yang sensitif.

c. Piezoelectric sebagai meteran getaran.

d. Piezoelectric pada bidang otomotif sebagai transducer untuk mendeteksi letupan, dengan mensamling getaran blok mesin.

e. Piezoelectric transducer unit electric drum untuk mendeteksi sentuhan stik drum.

\subsubsection{Musical Instrument Digital Interface (MIDI)}

Pada awalnya, setiap alat musik memiliki bahasanya sendiri sehingga tidak dapat dibaca oleh atau berkomunikasi antar alat musik lainnya. Agar suatu software dapat membaca perangkat musik lainnya, maka tahun 1980-an beberapa industri musik besar bergabung untuk menentukan standar bahasa yang dapat dibaca oleh berbagai instrumen. Standar bahasa itulah yang dikenal sebagai MIDI.

Dalam bahasa komputer, dikenal adanya dua jenis data suara, yaitu „Audio ${ }^{\text {"e dan „MIDI }}$. Perbedaan keduanya terletak pada format data. Misalnya saja kita merekam suatu organ atau keyboard ke dalam komputer dengan format ,audio (yang file extension-nya adalah .wav), hasilnya adalah suara yang sama persis. Demikian juga jika file-nya di-copy dan dibaca oleh komputer manapun juga, maka suara yang terdengar masih tetap suara asli organ atau keyboard tersebut.

\subsubsection{Dinamika musik dan velocity MIDI}

Salah satu kelebihan yang dimiliki MIDI adalah dapat membedakan velocity atau nilai kekerasan bunyi pada not yang dimainkan. Terdapat 128 level velocity not pada MIDI, dengan level 0 mewakili not mati atau tidak adanya not yang dimainkan, hingga level 127 yang mewakilkan not dengan kekuatan paling besar. Hal ini juga sesuai dengan kemampuan yang dimiliki sensor piezoelektrik yang dapat mengetahui kekuatan getaran dari suatu sumber bunyi. Derajat kekuatan atau kelembutan dalam bermusik disebut dinamika. Kekuatan tersebut berkaitan dengan amplitudo getaran yang menghasilkan bunyi. Contohnya, semakin kuat senar gitar dipetik hingga semakin jauh pergerakannya dari posisi semula, semakin kuat bunyi yang dihasilkan. Peningkatan kekuatan yang perlahan bisa membangkitkan gairah suatu aransemen musik. Sebaliknya, pelembutan yang perlahan dapat membawa perasaan yang menenangkan.

Pemain musik menegaskan sebuah not dengan memainkannya lebih kuat dari not disekitarnya. Yang mana ini disebut dynamic accent. Dengan takaran yang pas, sedikit perubahan pada dinamika bermusik dapat meningkatkan semangat dan perasaan bagi pemain maupun pendengar (Kamien, 1984)

\subsubsection{Mikrokontroller ATMEGA 328}

Mikrokontroler adalah sebuah sistem komputer fungsional dalam sebuah chip. Di dalamnya terkandung sebuah inti prosesor, memori (sejumlah kecil RAM, memori program, atau keduanya), dan perlengkapan input output. Mikroprosesor menjalankan tiga pekerjaan utama sistem komputer: (1) melakukan transfer data antara mikroprosesor sendiri dengan sistem memori atau I/O, (2) operasi aritmatika dan logika sederhana, dan (3) mengatur aliran program melalui pengambilan keputusan sederhana (Brey, 2003).

Mikrokonktroler digunakan dalam produk dan alat yang dikendalikan secara otomatis, seperti sistem kontrol mesin, remote controls, mesin kantor, peralatan rumah tangga, alat berat, dan mainan. Dengan mengurangi ukuran, biaya, dan konsumsi tenaga dibandingkan dengan mendesain menggunakan mikroprosesor memori, dan alat input output yang terpisah, kehadiran mikrokontroler membuat kontrol elektrik

untuk berbagai proses menjadi lebih ekonomis. Dengan penggunaan mikrokontroler ini maka :

- Sistem elektronik akan menjadi lebih ringkas

- Rancang bangun sistem elektronik akan lebih cepat karena sebagian besar dari sistem adalah perangkat lunak yang mudah dimodifikasi

- Pencarian gangguan lebih mudah ditelusuri karena sistemnya yang kompak

\subsubsection{Platform Arduino}

Arduino adalah platform pembuatan prototype elektronik yang bersifat open-source hardware yang berdasarkan pada perangkat keras dan perangkat lunak yang fleksibel dan mudah digunakan. Arduino ditujukan bagi para seniman, desainer, dan siapapun yang tertarik dalam menciptakan objek atau lingkungan yang interaktif. Arduino pada awalnya dikembangkan di Ivrea, Italia. Nama Arduino adalah sebuah nama maskulin yang berarti teman yang kuat. Platform arduino terdiri dari arduino board, shield, bahasa pemrograman arduino, dan arduino development environment.

\subsubsection{Sistem Komunikasi pada Arduino}

Arduino Uno memiliki beberapa fasilitas untuk dapat berkomunikasi dengan komputer, arduino lain, maupun mikrokontroler lainnya. ATMega328 ini dapat menyediakan serial komunikasi UART TTL $(5 \mathrm{~V})$, yang tersedia pada pin digital $0(\mathrm{Rx})$ dan 1 (Tx). Sebuah Atmega 16U2 pada sebuah saluran board komunikasi serialnya melalui USB dan muncul sebagai com port virtual untuk perangkat lunak pada komputer. Firmware Arduino yang digunakan adalah USB driver standar COM, dan tidak ada driver 
eksternal yang dibutuhkan. Perangkat lunak Arduino termasuk serial monitor yang memungkinkan data sederhana yang akan dikirim ke board arduino. Led Rx dan Tx pada board akan berkedip ketika data sedang dikirim melalui chip USB-to-serial dan koneksi USB ke komputer (tapi tidak untuk komunikasi serial pada pin 0 dan 1). ATMega328 juga mendukung komunikasi I2C dan SPI.

\section{METODE PENELITIAN}

\subsection{Blok Diagram Sistem}

Blok diagram adalah diagram dari sebuah sistem, di mana bagian Piezo Sensor sebagai alat masukan untuk mendeteksi getaran, Arduino Uno Sebagai alat pemrosesan, Hairless MIDI dan Loop MIDI merupakan aplikasi tambahan yang diinstal di laptop sebagai driver dan virtual kabel, EZ Drummer 2 sebagai aplikasi Drum. Proses kerja pada alat ini di tunjukkan pada gambar 3.1 berikut.

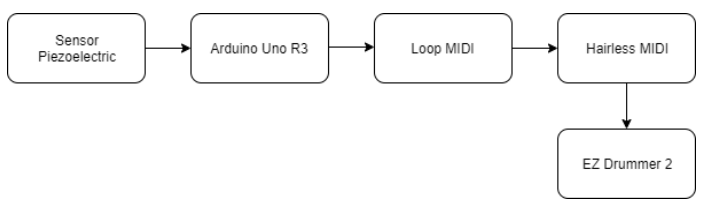

Gambar 3.5 Blok diagram sistem

\subsection{Flowchart Sistem}

Flowchart sistem ini menjelaskan proses berjalananya aplikasi seperti terlihat pada Gambar 3.2 berikut.

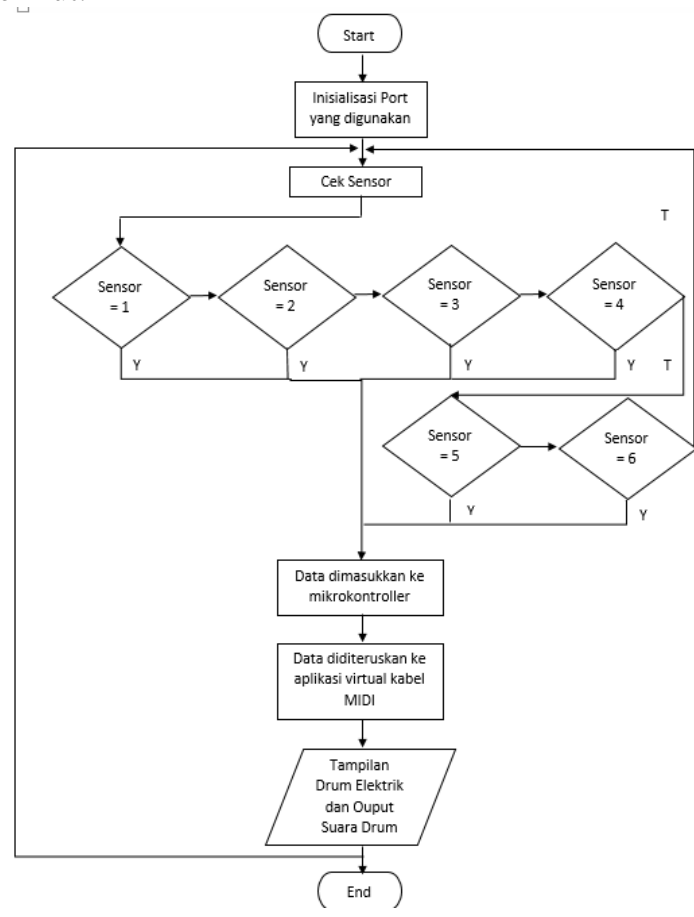

Gambar 3.2 Flowchart Sistem

Pada flowchart sistem di atas proses dimulai dengan menginsisialsasi sensor yang mana akan di tekan atau bergetar setelah menginput sensor, maka arduino akan melalui cek sensor. Sensor ada 6 piezoelectric, jika menekan salah satu akan masuk ke kondisi True, maka data akan diproses di mikrokontroller, kemudian diteruskan ke Loop MIDI dan Hairless Sebagai virtual. Di akhirnya Midi Drum akan bunyi ketika membuka EZ Drummer 2 sebagai aplikasi Drum. Dan proses berakhir apabila kita melepas kabel serial penghubung alat dan lapotop.

\section{HASIL DAN PEMBAHASAN}

4.1 Pengujian Hardware

Pengujian komponen dari alat MIDI Drum Controller ini terdiri dari minimum sistem Arduino Uno, 6 Piezoeletric, 6 Resistor. Menggunakan foam hitam untuk bagian atas dan sterofoam untuk bagian bawah, serta sementara menggunakan karton. Implementasi komponen yang terhubung pada minimum sistem arduino diletakkan pada sebuah papan kayu yang nantinya mudah dibawa. Adapaun implementasi hardware pada gambar 4.1

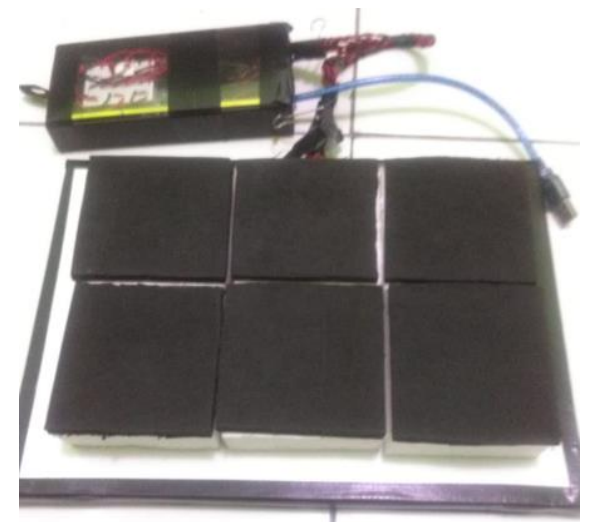

Gambar 4.1 Implementasi MIDI Drum Controller

Pada Gambar 4.1 merupakan sebuah alat MIDI Drum Controller untuk memainkan Drum, dianjurkan menggunakan stick drum untuk penggunaan alatnya.

\subsection{Pengujian Sensor Piezoelektrik}

Pengujian menggunakan sensor Piezoelektrik berfungsi untuk mengetahui getaran yang didapat setelah dipukul. Nilai yang dihasilkan dari pembacaan sensor ini adalah berupa nilai analog akan seberapa keras getaran pada sensor atau diam jika tidak ada getaran. Hasil dari pengujian sensor Piezoelektrik ini akan ditampilkan di Serial Plotter. Berikut skema rangkaian alat beserta hasil pengujian sensor Piezoelektrik

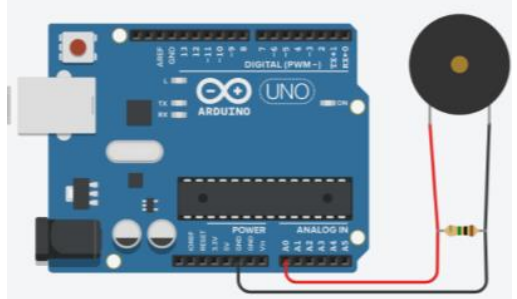

Gambar 4.2 Rangkaian Pengujian Sensor Piezoelektrik 
Gambar 4.2 Merupakan diagram blok atau gambar rangkaian dari sensor Piezoelektrik yang dihubungkan ke minimum sistem arduino menggunakan kabel jumper. Kutub Negatif pada piezo dihubungkan dengan resistor $1 \mathrm{Mega} \mathrm{Ohm}$ dan dilanjutkan untuk menuju ground, contohnya terdapat dalam gambar 4.2 dan menggunakan kabel berwarna hitam. Selanjutnya kutub positif dari piezoelektrik dihubungkan ke resistor dan dilanjutkan ke input Analog 0 (A0). Adapaun hasil pengujian dari dari modul GPS Neo-6m dapat dilihat pada tabel 4.1

Tabel 4. 1 Hasil Pengujian Sensor Piezoelektrik

\begin{tabular}{|l|c|l|}
\hline No & Nilai Getaran & Selisih \\
\hline 1 & 160 & 2 miliseccond \\
\hline 2 & 210 & 2 miliseccond \\
\hline 3 & 240 & 2 miliseccond \\
\hline 4 & 270 & 2 miliseccond \\
\hline 5 & 300 & 2 miliseccond \\
\hline
\end{tabular}

Pada tabel pengujian di atas dilakukan dengan cara menekan piezo tersebut Maka akan mendapatkan nilai getaran yang akan digunakan sebagai dinamika pukulan Drum. Dan selisih / delay yang digunakan 2 miliseccond. Untuk melihat Grafik dari getaran yang dipukul dapat dilihat melalui program arduino dengan menggunakan Serial Plotter seperti gambar 4.3

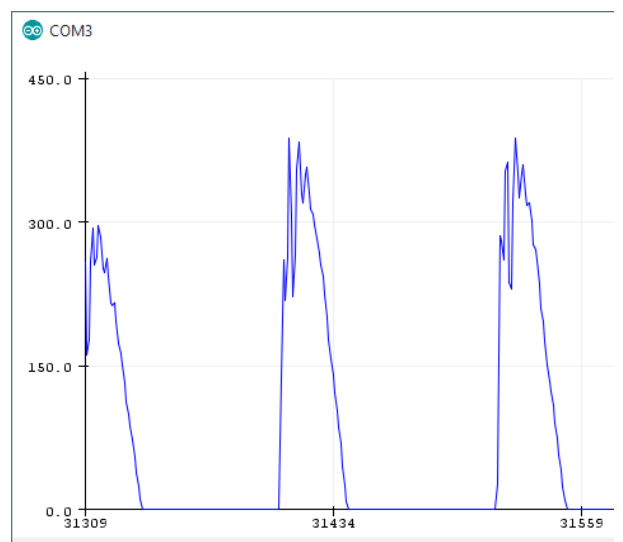

Gambar 4.3 Pengujian Serial Ploter pada Sensor Piezoelektrik

Pada gambar diatas menunjukkan grafik jika terjadi getaran, dengan ditekan sebanyak 3 kali secara pelan menggunakan jari, maka akan keluar grafik seperti diatas dengan menggunakan Serial Plotter. Angka yang disebelah kiri adalah nilai yang akan digunakan untuk inputan pukulan drum, sedangkan yang angka sebelah kanan merupakan waktu dengan ukuran miliseccond.

\subsection{Pengujian Bahan Drum}

Pengujian menggunakan 2 Bahan yang berbeda yaitu dengan Bahan yang keras dan lembut. Bagian yang keras menggunakan papan plastik seperti bahan KTP, sedangkan bagian yang lembut, menggunakan foam hitam. Percobaan pertama menggunakan Foam Hitam seperti gambar berikut

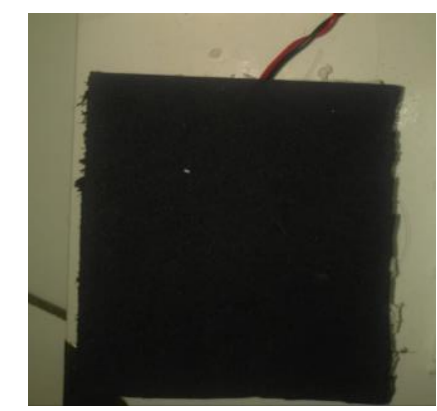

Gambar 4. 4 Pengujian Foam Hitam

Pengujian menggunakan 2 Bahan yang berbeda yaitu dengan Bahan yang keras dan lembut. Bagian yang keras menggunakan papan plastik seperti bahan KTP, sedangkan bagian yang lembut, menggunakan foam hitam. Percobaan pertama menggunakan Foam Hitam seperti gambar berikut

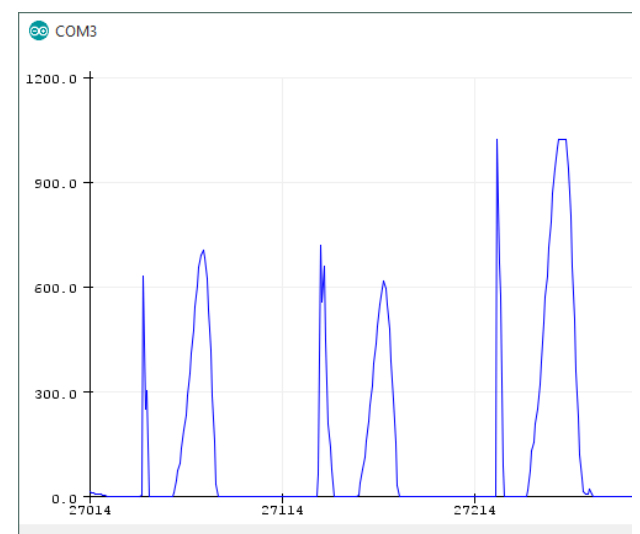

Gambar 4. 5 Pengujian Foam Hitam menggunakan Serial Plotter

Gambar diatas merupakan hasil pengujian dengan menekan bagian atas foam hitam dengan keras sebanyak tiga kali pukulan, tampak hasil yang didapatkan dengan nilai 700, 700, dan 1000. Kemudian selanjutnya pengujian menggunakan bahan pelastik tipis seperti gambar berikut.

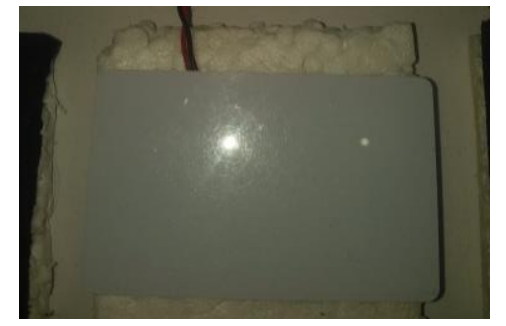

Gambar 4. 6 Pengujian Pelastik Tipis

Lapis bagian atas merupakan Pelastik Tipis dan dibawahnya ditempel piezoelektrik dan bagian 
alasnya sama menggunakan sterofoam. Berikut adalah hasil pengukian menggunakan pelastik tipis

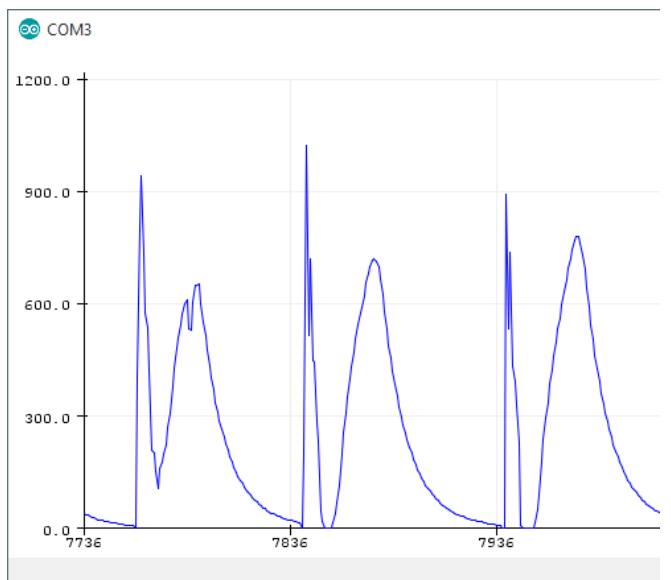

Gambar 4. 7 Pengujian Pelastik Tipis menggunakan Serial Plotter

Gambar diatas merupakan hasil pengujian dari sensor piezoelektrik yang dilapis Pelastik Tipis menggunakan serial ploter. Nilai yang didapatkan dengan memukul keras sebanyak tiga kali adalah sekitar 900, 1000, dan 900.

Kesimpulannya adalah jika dilihat dari grafik antara Foam Hitam dan Pelastik maka dapat ditemukan perdaan jarak yang berbeda. Jika menekan Foam Hitam getaran yang ditangkap akan cepat redam getarannya dibandingkan dengan menggunakan Pelastik Tipis, terlalu sensitif dan masih tersisa getarannya. Jadi Foam Hitam lebih optimal dibandingkan dengan Pelastik Tipis.

\subsection{Halaman LoopingMIDI}

LoopMIDI digunakan untuk membuat virtual MIDIport sebagai penghubung ke aplikasi lain pada Windows. Keuntungannya adalah komunikasi data bisa menggunakan USB ke Laptop. Berikut adalah tampilan loopMIDI

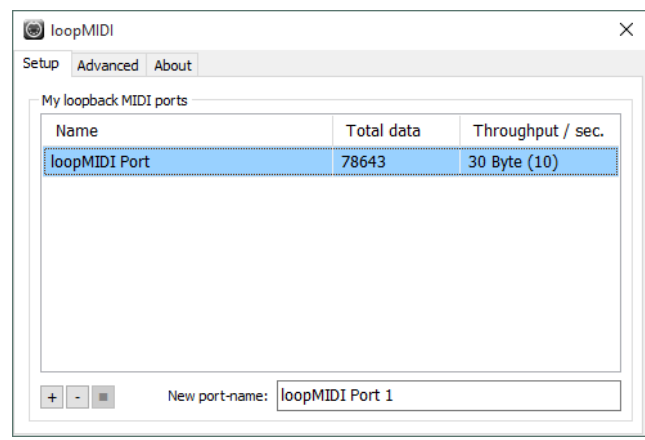

Gambar 4.8 loopMIDI

Pada Gambar diatas terdapat port dengan nama loopMIDI Port dengan Total data 78643 merupakan data yang sudah lewat jika menekan sensor piezoelektrik. Sementara Throughput / Sec dengan 30 Byte (10) merupakan data real time dalam satuan Byte yang masuk dihitung perdetik. Berikut adalah pengujian menggunakan loopMIDI dapat dilihat pada Tabel 4.2

Tabel 4. 2 Hasil Pengujian loopMIDI

\begin{tabular}{|c|c|c|}
\hline No & Total Data & Throughput/sec \\
\hline 1 & 6 & $6(2)$ \\
\hline 2 & 12 & $6(2)$ \\
\hline 3 & 33 & $21(2)$ \\
\hline 4 & 66 & $33(11)$ \\
\hline 5 & 102 & $36(12)$ \\
\hline 6 & 117 & $15(5)$ \\
\hline 7 & 159 & $42(14)$ \\
\hline 8 & 204 & $45(15)$ \\
\hline 9 & 261 & $57(19)$ \\
\hline 10 & 288 & $27(9)$ \\
\hline
\end{tabular}

Dari hasil pengujian diatas dilakukan dengan menekan sembarang piezo elektrik dengan tekanan yang berbeda dan waktu menekan, sehingga menghasilkan data diatas. Total Data adalah seluruh data yang telat lewat, sedangkan Troughput/sec untuk melihat secara real time berapa banyak data yang lewat dalam satuan Byte/sec.

\subsection{Halaman Hairless Midi Serial}

Hairless Midiserial berfungsi untuk menghubungkan port COM 3 dari Arduino menuju MIDI Out dengan Virtual yang telat dibuat menggunakan loopMIDI tadi.

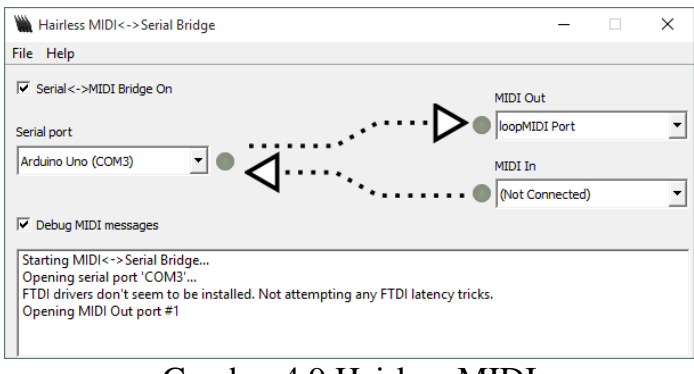

Gambar 4.9 Hairless MIDI

Gambar 4.9 merupakan gambar dari tampilan Hairless MIDI dengan Serial Port Arduino Uno (COM 3) dan MIDI Out menggunakan virtual loopMIDI port. Untuk dapat terhubung harus menggunakan Baudrate yang sama dengan memlih File dan Pereference dan menggantinya dengan 57600 Baudrate. Hasil Pengujian dapat dilihat sebagai pada tabel berikut

Tabel 4. 3 Hasil Pengujian Hairless Midi

\begin{tabular}{|c|c|c|c|}
\hline Waktu & Chanel & Note & Velocity \\
\hline 2.667 & 1 & 41 & 94 \\
\hline 2.728 & 1 & 41 & 0 \\
\hline 7.189 & 1 & 36 & 61 \\
\hline 7.251 & 1 & 36 & 0 \\
\hline 10.233 & 1 & 69 & 100 \\
\hline 10.294 & 1 & 69 & 0 \\
\hline 12.625 & 1 & 47 & 61 \\
\hline 12.686 & 1 & 47 & 0 \\
\hline
\end{tabular}




\begin{tabular}{|c|c|c|c|}
\hline 14.669 & 1 & 11 & 71 \\
\hline 14.731 & 1 & 11 & 0 \\
\hline 16.09 & 1 & 57 & 62 \\
\hline 16.152 & 1 & 57 & 0 \\
\hline
\end{tabular}

Tabel 4.3 Merupakan hasil pengujian alat dengan aplikasi Hairless Midi. Channel merupakan port yang digunakan untuk MIDI Drum, Note merupakan Tipe dari Suara drum yang digunakan sesuai dengan input analog pada Arduino Uno, dan Velocity merupakan dinamika dari keras pelannya sensor piezo elektrik yang digunakan.

\subsection{Pengujian EZ Drummer}

EZ Drummer merupakan aplikasi produce musik terutama drum, terdapat beberapa variasi suara drum, serta dapat terhubung secara Real Time antara alat dan Output Suara Drum.

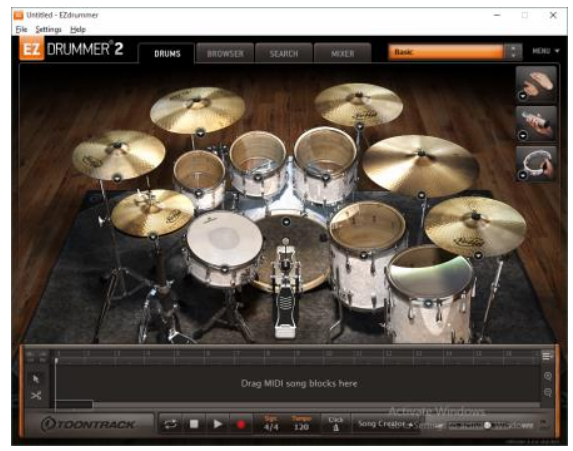

Gambar 4.10 EZ Drummer

Setelah semua alat dan software terpasang dengan baik, langkah terakhir dengan menghubungkan antara EZ Drummer dengan. Menambah MIDI device pada setting, dan menggunakan loop MIDI port.

Tabel 4. 4 Hasil Pengujian Alat menggunakan EZ Drummer

\begin{tabular}{|c|l|l|c|}
\hline No & Pengujian & \multicolumn{1}{|c|}{ Keterangan } & Hasil \\
\hline 1 & Sensitivitas & $\begin{array}{l}\text { Sensivitas pad ketika } \\
\text { dipukul dan tidak dipukul }\end{array}$ & $\checkmark$ \\
\hline 2 & $\begin{array}{l}\text { Kualitas } \\
\text { Suara }\end{array}$ & $\begin{array}{l}\text { Hasil output suara yang } \\
\text { baik }\end{array}$ & $\checkmark$ \\
\hline 3 & $\begin{array}{l}\text { Kuat- } \\
\text { lemah } \\
\text { Pukulan }\end{array}$ & $\begin{array}{l}\text { Velocity / Dinamika } \\
\text { untuk menentukan keras } \\
\text { pelannya sebuah suara }\end{array}$ & $\checkmark$ \\
\hline 4 & $\begin{array}{l}\text { Kebutuhan } \\
\text { Drum }\end{array}$ & $\begin{array}{l}\text { Produk dapat memenuhi } \\
\text { kebutuhan suara Drum }\end{array}$ & $\checkmark$ \\
\hline 5 & Real Time & $\begin{array}{l}\text { Ketepatan suara dengan } \\
\text { apa yang dipukul sesuai } \\
\text { dan tidak delay }\end{array}$ & $\checkmark$ \\
\hline
\end{tabular}

\section{KESIMPULAN DAN SARAN}

\subsection{Kesimpulan}

Berdasarkan hasil pengujian dapat disimpulkan :

1. Pad pada alat MIDI Drum Controller sesuai dengan aplikasi EZ Drummer saat dimainkan sesuai dengan pengujian.

2. Terdapat dinamika untuk keras kecilnya pukulan yang mempengaruhi output suara dapat dilihat pada Velocity yang berubah sesuai dengan keras lemahnya pukulan.

3. Lebih baik menggunakan foam hitam untuk dijadikan pelapis sensor Piezoelektrik.

4. Alat ini merupakan Musical Instrument Digital Interface (MIDI) Drum.

5. Alat ini praktis mudah untuk dibawa karena bobotnya yang ringan.

\subsection{Saran}

Berdasarkan penelitian yang telah dilakukan maka penulis dapat memberikan saran-saran untuk pengembangan selanjutnya karena penelitian ini masih terdapat banyak kekurangan, sehingga untuk penyempurnaan dapat ditambahkan :

1. Membuat Aplikasi Sendiri supaya muudah mengintegrasi antara alat dengan software.

2. Meriset bahan yang lebih murah dan mencari bahan yang mendekati feel drum asli.

\section{DAFTAR PUSTAKA}

[1] Edy, Rosi Tamala, 2016, Pengembangan Midi Drum kontroler Berbasis Mikrokontroler ATMEGA 2560. Jurnal Pendidikan Seni Musik

[2] Pratama, Muhammad Rizki, 2016, Implementasi Fuzzy Logic dalam Perancangan Drum Elektrik Berbasis Midi Menggunakan Perangkat Android dan Arduino Uno, Jurnal Ilmu Komputer

[3] Kurniawan, Wahyu. 2015, Analisis Dan Perancangan Perangkat Keras MIDI Drum Kit Elektrik Berbasis Mikrokontroller Arduino, Jurnal Teknik Informatika, Februari 2015

[4] Faisal. 2017, Rancang Bangun Perangkat Drum Elektrik Berbasis Mikrokontroler Dengan Memanfaatkan Bahan Pelastik, Jurnal Teknik Informatika, Maret 2017

[5] Pratama, Nopebriansyah Angki, 2015, Pengembangan Midi kontroler Berbasis Mikrokontroler dengan Mekanisme Sentuh. Jurnal Pendidikan Seni Musik

[6] Irawan, J.D., Prasetio S., Wibowo, S.A. 2018, Early Warning System For Building Automation System, Jurnal Teknologi Informasi Vol. 6 No. 2 